\title{
Blended learning for sustainable education: Moodle-based English for Specific Purposes teaching at Kryvyi Rih National University
}

\author{
Nadiya Holiver, Tetiana Kurbatova*, and Iryna Bondar \\ Kryvyi Rih National University, 11 Vitalii Matusevych Str., Kryvyi Rih, 50027, Ukraine
}

\begin{abstract}
The article deals with the experience of implementing Information Communication Technologies (ICT) into ESP (English for Specific Purposes) teaching and learning. Informatization and application of innovations in education has resulted in emergence of e-learning. While Moodle is one of the most popular Learning Management Systems (LMS) and it enables and facilitates the shift to the student-centered education, the article highlights its implementation and adjustment to the specific nature of teaching and learning languages for specific purposes at Kryvyi Rih National University. The article touches upon reasons for applying Moodle to language teaching/learning and its advantages as a complement to the traditional face-to-face, or classroom, mode, thus combining them into what is referred to as blended learning, or b-learning. Both the teachers and learners interviewed demonstrated positive attitudes to using the platform in their practices. Besides, the article touches upon Moodle-based opportunities of managing the content and monitoring students' activities both in general and by individual courses. As Moodle is a web-based distance education platform not initially developed for language learning, the article invites discussion on advantages and disadvantages of its application to teaching/learning foreign languages and finding out which factors may allow language teachers and learners to boost its use and reach the set goals.
\end{abstract}

\section{Introduction}

The concept of Sustainable Development forms the foundation for the world community's actions aimed to preserve our civilization for generations to come. Sustainable development is based on mutual understanding and interaction of nations, which is impossible without knowing at least one foreign language.

Sustainable Education or Education for Sustainable Development allows every human being to acquire the knowledge, skills, attitudes and values necessary to shape a sustainable future. It requires participatory teaching and learning methods that empower learners to change their behaviour and take action for sustainable development [1]. All this requires a common language, a lingua franca, to facilitate any kind of international communication in the sphere of sustainable development.

The post-industrial society is characterized by a high degree of informatization and application of innovations impacting every area of human life, education being one of them. Creation of computers and the Internet have provided teachers and learners with both learning materials and tools that facilitate knowledge acquisition and retention and resulted in wide implementation of
Information and Communication Technology (ICT) into education $[2, \mathrm{p} .38]$.

Information and Communication Technology has evoked new approaches to training as a whole $[3,4]$ and to teaching foreign languages in particular and resulted in emergence of e-learning - web-based distance education platforms offered by Learning Management Systems. These multi-purpose software applications complement the current learning practices combining traditional (classroom-based learning) and virtual (elearning) formats of teaching/learning any content including foreign languages. The combination of the kind is often referred to as blended learning. Among a variety of free and commercial e-learning systems, Moodle is a free and open source e-learning software platform [5, p. 51].

Though originally developed for distance learning, Moodle offers helpful and motivating tools for teaching/learning foreign languages both online and in class, thus increasing efficiency of independent and individual work. Multiple combinations of Moodle elements (test, wiki, forum, chat, glossary, assignment etc.) enable teachers to settle didactic and learning problems and tasks and reach particular goals. Distance learning is associated with its accessibility to many people $24 / 7$. 
Over the last few decades, foreign language instruction has been one of the leading educational areas in which technology is playing a salient role. It should be noted that the more technologies are incorporated into foreign language instruction, the more opportunities are provided for teachers and students to become globally connected and educated. Modern technologies are an integral part of today's ESP training giving students a break from traditional activities, yet reinforcing their language learning skills through the so-called language immersion defined as the process of students' plunging into the foreign language environment by means of either excluding or limiting the use of their mother tongue [6].

Learning Management Systems are used by education specialists to create and teach courses in distance education environment. In blended courses, classroom lessons and online courses are used together and this flexibility increases accessibility of learning activities and opportunities for interaction [7, p. 597]. Moodle is an open-source learning management system that allows users to create online courses. It is easy to install and use; there are hosted or one-click options available. Being a kind of ICT, it leads to a new quality of instruction and reflects the modern tendencies in education by providing continuous access to learning resources according to the anytime-anyplace principle. Flexibility in learning enables learners to learn when they want (frequency, timing, duration), how they want (modes of learning), what they want (learning content) and where they prefer to learn. Besides, the "anytimeanywhere-anyhow" learning is characterized by loosening logical and didactic constraints [7]. The Moodle platform offers time and place flexibility as an essential advantage of the innovative teaching-learning toolkit as learning activities can be adjusted to meet learners' specific needs constrained by busy schedules, lack of time, psychological and other issues. The target language competencies can be practiced in the environment that closely resembles the real-life one or even in actual communication situations. The platform provides various language support including vocabulary and grammar references and training, speech patterns, etc. It is also a new inventory for developing a human of the new information society capable of mobile-assisted life-long learning.

Theoretical and practical aspects of use of ICT in education in general and in teaching/learning in specific areas are widely covered by scientists and practitioners $[8,9,10,11]$.

Much attention is also paid to LMS as they produce a significant impact on the educational process [12]. As software systems that combine different tools used to "systematically deliver content online and facilitate the learning experience around that content" [13], LMS can complement traditional classroom-based formats, resulting in b-learning.

Among the variety of platforms providing tools for virtual education, Moodle is one of the most popular LMS in the world with 226 countries applying them for educational purposes [14]. Not initially designed for language learning, Moodle, however, is globally used in this field, adding to enhancement of language acquisition. Yet, potential of this platform in teaching/learning languages does not receive sufficient coverage in national scientific literature.

The research proved efficiency of the Moodle system application to teaching and learning foreign languages at higher educational institutions of Ukraine taking the practice of Kryvyi Rih National University as an example. The objectives of this research include finding out what features of the Moodle system are used by the English teachers of the University, what are advantages and disadvantages of using Moodle features and working out some recommendations to further wider implementation of the system. The research aims at studying involvement of the University language teachers and their methodology through understanding and interpreting their opinions in terms of Moodle integration in their everyday teaching practices.

\section{Methodology of the research}

The conceptual framework of this research is based on conceptualization of efficiency of using the learning management system Moodle for University teachers and students learning English as a second language for specific purposes. The researchers utilized cluster sampling in the study.

The number of participants in the research made 13 full-time language teachers of Kryvyi Rih National University, Ukraine, training future engineers for a variety of industries including mining, economy, management, IT, electric engineering, machine building, ecology, etc. They were all interviewed on the issues relevant to the present research. The research instruments involved application of questionnaires and interviews.

\section{Results of the research}

In Ukraine, main trends in forming higher engineering education involve changes in the structure, organization, forms and methods of training that correspond to the prevailing trends of the world educational system. Changes in the training structure and content call for applying both conventional and innovative forms and methods of foreign language learning and teaching accompanied by up-to-date technologies.

Implementation and active application of ICT to education is one of the priorities required for its reforming. Despite difficult economic conditions, most Ukrainian higher educational institutions, especially engineering ones, are provided with equipment for introducing online learning technologies into their training process [15, p. 141].

The Foreign Languages Department of Kryvyi Rih National University is intensively using innovative technologies in the training process, this being supported by the following facts. The University provides a 24hour access to the Internet (including the wireless one) for its employees and students. Most teachers, lecturers and students of the University are computer-literate. 
Analysis of the current facilities of Kryvyi Rih National University and students' polling allows us to conclude that provided educational and reference data are sufficient enough to ensure a successful training process in terms of foreign language teaching and learning as the Foreign Languages Department has three specialized multimedia laboratories at its disposal, most students have their own digital devices and an access to the Internet. There is evident lack of face-to-face hours of English training (68 hours per year for 1-2-year courses with the exception of a 3-year course for students majoring in software development (a 3-year course, 204 contact hours) and a 4-year course for foreign economic activity management students (340 contact hours)). Application of ICT creates suitable conditions for students training as there is a constant access to training resources any time in the user-friendly environment).

The virtual training environment on the learning management platform Moodle was introduced several years ago. Since then, Moodle has been used more and more intensively by both students and lecturers. A lot of authentic and didactically-enriched materials have been accumulated, that providing the basis for a variety of authors' training courses. Within the courses, teachers can share materials, manage communication and set up activities.

While designing the courses, the developers used special modules of Moodle in support of learning foreign languages. The courses are designed on the basis of sound learning principles tailored to aid the development of practical skills such as listening comprehension skills (European Integration through Education; Language Skill assessment; Examination Videos; Phonetic Skills Development); reading and writing skills (Business Law; Tests for IT Students); speaking and specific terminology (English for Mining Engineers; English for Mechanical and Electrical Engineering; Metallurgical Vocabulary) [16].

Moodle for learning English is flexible enough to support innovative blended teaching methods. The given approach is of great value for both students and teachers. Students are engaged into doing independent or solo work at any time convenient, while teachers are able to control and check students' works without auxiliary workload. The platform provides an opportunity to develop online interactive courses that boost students' creativity, outlook and cognitive abilities, thus enhancing training outcomes.

Moodle implementation at Kryvyi Rih National University included two stages. On the first stage, the University lecturers studied possibilities of the virtual training environment and developed a number of courses for first- and second-year students.

The stage included:

- substantiating theoretical and methodological principles of the research;

- developing a programme of the research;

- determining the aim, objectives and methods of the research;

- developing and systematizing training electronic courses and testing sets;
- updating available methods of using ICT in foreign language teaching and learning.

In practice, the University English teachers who used Moodle on a regular basis in their instruction covered the following system features:

- creating and managing course content;

- developing assignments, exercises, and tests;

- providing students' workgroup and peer review;

- providing students' journal and document submission;

- providing access to online quizzes, surveys, videos;

- assessing students' knowledge and providing grades and ratings.

As for creating and managing course content, it appeared to be the most widespread activity as numerous materials, exercises and tests were uploaded by means of this Moodle feature. This is particularly applicable to providing listening assignments so that students can visit anywhere and anytime and practice their listening skills online. Students are encouraged to use embedded glossaries as many of them have a very low knowledge of English vocabulary. It eliminates the necessity to provide students with loads of printed materials and saves a lot of teachers' time and efforts. If students come across comprehension problems in their reading or listening activities, they can look up the necessary vocabulary by using glossary links anytime.

Peer review is a good opportunity for students to learn something new and consolidate their own knowledge and skills through commenting on other students' works and analyzing their mistakes. Teachers also treated online quizzes and surveys as a good chance to make a difference in their everyday instruction routine. Students' grades and ratings encourage fair and transparent assessment of their success in foreign language learning.

The mentioned work continued on the second stage. Accumulated experience allowed developing courses by integrating authentic or didactically supported multimedia resources and a variety of communicative learning activities for graduate and postgraduate students, varying task types and their character and making them more interactive and relevant to students' needs. Besides, the e-tools of the Moodle platform are applied to monitoring students' results through active communicative teacher-student or student-student contact (by using e-mail, forum, chat) and controlling students' learning activity by means of feedback, evaluation and statistics. All this determines opportunities to increase quality of provided resources as well as assessing efficiency of the blended learning process. Obtaining speaking skills is critical in learning foreign languages. Thus, when we run out of discussion time in a face-to-face session, Moodle forum is used to continue online. Student and the teachers spend time formulating thoughtful responses and dig into deep discussions. Moodle breaks courses into topics that form a structural pathway through all the materials studied providing blended learning. To fulfill these objectives, there were developed 16 courses on English grammar, vocabulary, country study, etc. for undergraduates, graduates and post-graduates of all specialisms [16] (Fig. 1, 2). 


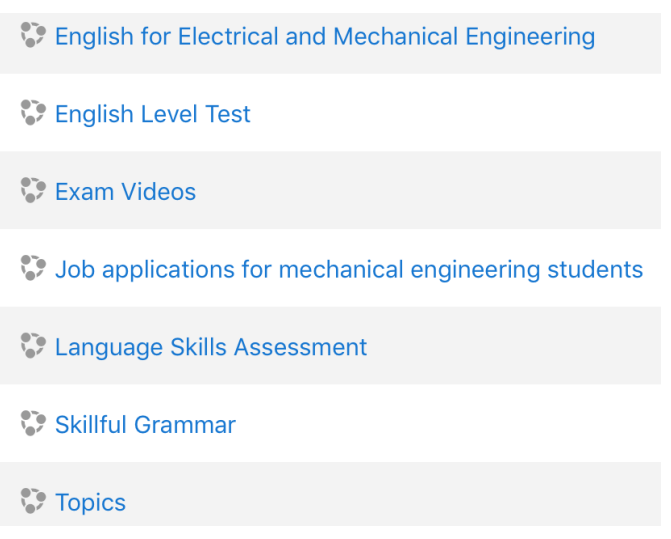

Fig. 1. A fragment of the list of courses in Moodle

Listening Comprehension Test

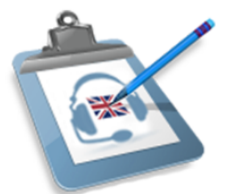

This test consists of a video with 10 questions to check the comprehension. First watch the video, then browse the questions (go to LSA - Listening Comprehension below) to get the idea of what you should focus on. Watch the video again and pass on to the test (LSA - Listening Comprehension Test below) where you are to choose 1 (ONE) correct answer.

The limit is $\mathbf{2 0}$ minutes.

Note: The order of the questions is random.

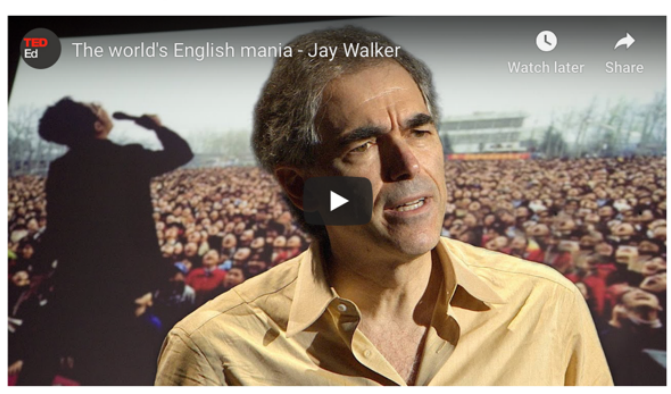

LSA - Listening Comprehension

$\checkmark$ LSA - Listening Comprehension Test

Fig. 2. A fragment of the Language Skills Assessment course

The scope and results of Moodle potentials implemented in Kryvyi Rih National University for arranging students' individual and solo work are summarized in Table 1.

Table 1. The scope and results of use of Moodle for arranging students' individual and solo work.

\begin{tabular}{|c|l|l|l|}
\hline Stages & \multicolumn{2}{|c|}{ Content } & \multicolumn{1}{|c|}{ Results and reporting } \\
\hline I & - development of & Results: & and \\
required and elective & - development \\
courses (grammar, & accumulation of author's \\
lexis, country studies, & courses and the tests base; \\
etc.) for 1- and 2-year & - arrangement of the available \\
students of all & archive of training resources; \\
specialisms; & - ICT-based updating of \\
- practical testing & $\begin{array}{l}\text { current teaching methods } \\
\text { Reporting documents: } \\
\text { - printed log-files (with } \\
\text { Moodle-based activity } \\
\text { duration, completed tasks, etc. } \\
\text { indicated) }\end{array}$ \\
\hline II & $\begin{array}{l}\text { - wide application of the } \\
\text { developed courses to } \\
\text { learning and its quality }\end{array}$ & $\begin{array}{l}\text { Results: } \\
\text { - implementation of b-learning } \\
\text { methods; }\end{array}$ \\
\hline
\end{tabular}

\begin{tabular}{|c|l|l|}
\hline Stages & \multicolumn{1}{|c|}{ Content } & \multicolumn{1}{|c|}{ Results and reporting } \\
\hline & $\begin{array}{l}\text { monitoring; } \\
\text {-development of } \\
\text { courses for graduates } \\
\text { and postgraduates; } \\
\text { - further test base } \\
\text { development }\end{array}$ & $\begin{array}{l}\text { generated teacher-student, } \\
\text { student-teacher-student, } \\
\text { student-student modes of } \\
\text { interaction enabling novel } \\
\text { teaching/learning } \\
\text { communication forms; } \\
\text { - attendance monitoring and } \\
\text { students' work control; } \\
\text { - enhancement of the test base } \\
\text { (resulted in determining the } \\
\text { complexity threshold and } \\
\text { fixing individual and group } \\
\text { problems) } \\
\text { Reporting documents: } \\
\text { - the system weblog; } \\
\text { - the printed test base and its } \\
\text { analysis; } \\
\text { - course attendance reports }\end{array}$ \\
\hline
\end{tabular}

So, Moodle provides teachers with a feature enabling them to analyze students' activity in Moodle both in general and for each course and thus introduce necessary adjustments as for relevance of the activity, its complexity, degree of the material digesting etc. that is, a teacher can monitor frequency of the students' visits, detect problems and decide on ways of the problem settling and directions of further work. It should be noted that students also have access to their grade records, this producing a significant motivating effect. Fig. 3, 4, 5, 6 present various types of reporting in Moodle.

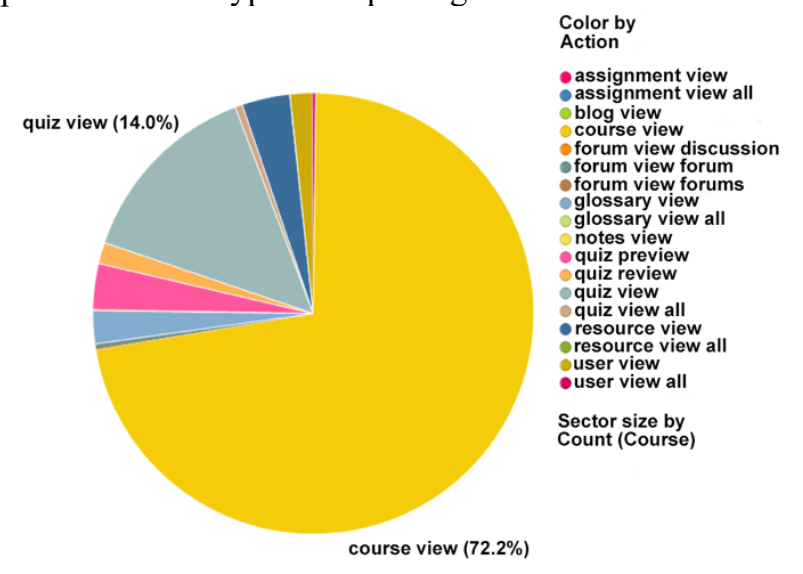

Fig. 3. General analysis of students' viewing resources

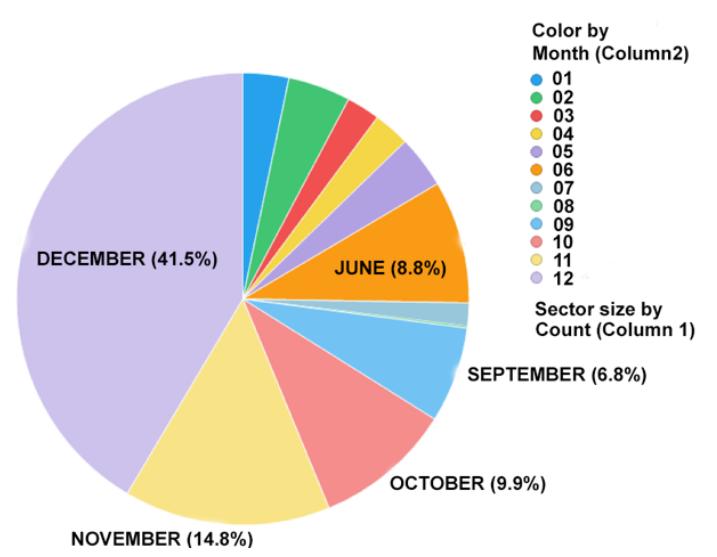

Fig. 4. Students' activity by months. 


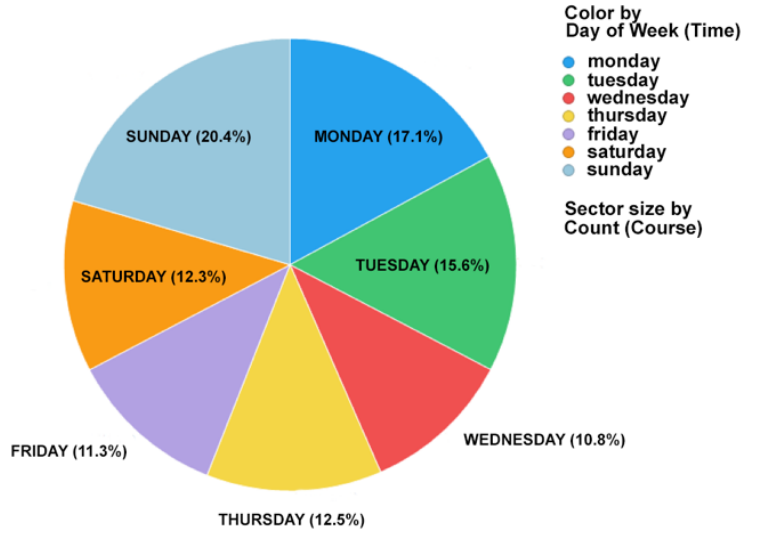

Fig. 5. Students' activity by days of the week.

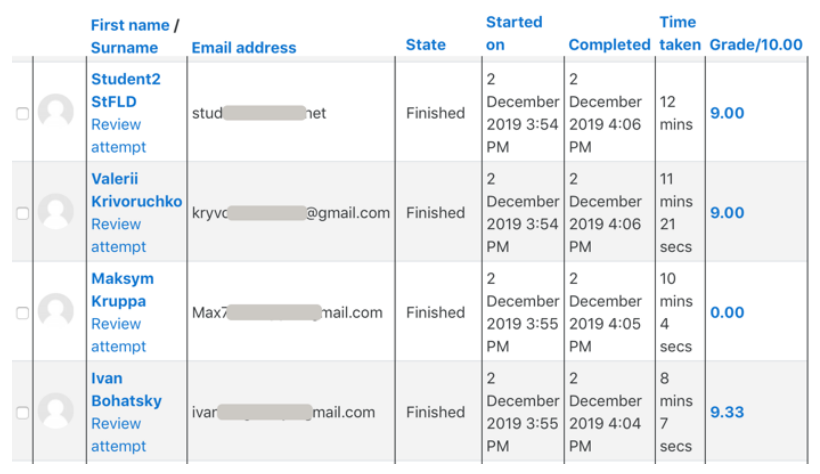

Fig. 6. Test results.

\section{Conclusions}

Analysis of new forms of training activities in case of the Moodle platform use enables the following conclusions. Implementation of ICT in higher education is one of the priorities of its informatization. The Moodle platform has some evident advantages (time-space independence (the anytime-anyplace principle), convenience and flexibility, the student-friendly environment to motivate and boost learners' self-esteem, etc.). It is an effective supplement to conventional forms of training organization that encourages foreign language learning.

According to conducted interviews of the English teachers of Kryvyi Rih National University engaged in the research, the uttermost and most evident advantage of Moodle application to foreign language teaching and learning is boosting student-centered learning. Students are able to obtain a huge amount of language practice using online materials either authentic or developed by their teachers. They can choose the training content and supporting activities according to their own interests and language proficiency levels. Speaking about the anytime-anywhere principle of the Moodle system, it provides almost limitless opportunities for studying languages both in and out of class. This principle is well supported by Moodle course convenience of control and administration as teachers are viewed as course developers and administrators.

The file types offered by the platform enable increasing future engineers' cognitive activity by presenting training materials in a variety of ways supported by a great amount of reference sources (grammar explanations, templates of project tasks, presentations, reports) in PDF. PowerPoint presentations are applied as both teaching tools and tasks for students' independent and solo work. Thus, students are able to improve their knowledge and skills of their future specialisms through being exposed to advanced developments in engineering presented in English.

The Moodle platform is also applied to forming professional skills through second language learning in terms of professional English of specialisms with its further application as a means of business communication and intercultural exchange.

The research has proved that Moodle enables incorporation of conventional and innovative forms and methods of training (b-learning) being an efficient tool of sustainable foreign language teaching and learning. It is also an efficient tool to make university language training more cost- and time-effective. Teachers can save time, paper and other resources by using the platform as they are able to create and store their materials online. Mobile devices such as netbooks, laptops, iPads, tablets, smartphones, digital cameras, mp3-players, personal digital assistants and electronic books have become very widespread, especially among young people. They are incorporated into modern ESP classroom and become a subject for both research and sustainable practice in technology-enhanced language learning.

However, in spite of numerous advantages of using the Moodle platform, there are also some disadvantages of using it in b-learning. The drawbacks of applying the Moodle system in Ukrainian higher educational institutions can concern some technical, instructional issues and efficiency of learning results. The technical problems arise from instability of the internet connection, lack of reliable equipment and computerliterate staff. Unfortunately, only 8 out of 13 English teachers are currently using the Moodle platform on a constant basis. The instruction problems are caused by evident lack of training and time required for teachers to get acquainted with the digital platform as some features are reported to be either irrelevant for foreign language teaching or quite demanding for both teachers and students to master. Yet, this powerful tool of training management is not used in Ukraine as widely as it should be, in particular concerning foreign language training, this making the basis for further theoretical and practical investigations into Moodle and its use for blended learning.

\section{References}

1. UNESCO World Conference on Education for Sustainable Development Conference Report by the General Rapporteur Heila Lotz-Sisitka, Professor, Rhodes University (2014). https://www.plymouth.ac.uk/students-andfamily/sustainability/sustainability-education/esd. Accessed 15 May 2019

2. M.I. Striuk, S.O. Semerikov, A.M. Striuk, Mobility: a systems approach. Information Technologies and 
Learning Tools 49(5), 37-70 (2015). doi:10.33407/itlt.v49i5.1263

3. S.O. Semerikov, M.I. Striuk, N.V. Moiseienko, Mobilne navchannia: istoryko-tekhnolohichnyi vymir (Mobile learning: historical and technological dimension), in Teoriia $i$ praktyka orhanizatsii samostiinoi roboty studentiv vyshchykh navchalnykh zakladiv (Theory and practice of organization of independent work of students of higher educational institutions), ed. by O.A. Konoval (Knyzhkove vydavnytstvo Kyreievskoho, Kryvyi Rih, 2012), pp. $188-242$

4. S.O. Semerikov, A.M. Striuk, Kombinovane navchannia: problemy i perspectyvy zastosuvannia $\mathrm{V}$ udoskanalenni navchalno-vykhovnoho protsesu i samostiynoi roboty studentiv (Blended learning: problems and prospects of application in improving the educational process and students' independent work), in Teoriia ta praktyka orhanizatsii samostiinoi roboty studentiv $v$ vyshchyh navchalnykh zakladiv: monoghrafiia (Theory and practice of organization of independent work of students of higher educational institutions), ed. by O.A. Konoval (Knyzhkove vydavnytstvo Kyreievskoho, Kryvyi Rih, 2012), pp. 135-163

5. N. Gunduz, D. Ozcan, Implementation of the Moodle system into EFL classes. Teachers Professional Development 19(1), 51-64 (2017)

6. V. Bošković, T. Gajić, I. Tomić, Moodle in English Language Teaching (2014), https://www.researchgate.net/publication/26923162 9_Moodle_u_nastavi_engleskog_jezika. Accessed $1 \overline{5}$ May $20 \overline{19}$

7. H. Tüzün, H.Ç. Sarıca, N.M. Çetin, The adaptation of a residential course to web-based environment for increasing productivity, in Online Course Management: Concepts, Methodologies, Tools, and Applications (Information Resources Management Association, 2018), pp. 597-608

8. O.A. Shcherbyna, K.S. Vasylieva, Designing a Moodle site for a higher educational institution and organizing works on its creation. Visnyk Lvivskoho derzhavnoho universytetu bezpeky zhyttiediialnosti 9, 35-40 (2014)

9. M.N. Wagner, Perspectives of Introduction of the Mobile-Assisted Language learning Technology. Intern. J. of Environ. and Sc. Ed. 11(15), 8562-8571 (2016)

10. Ye.O. Modlo, S.O. Semerikov, P.P. Nechypurenko, S.L. Bondarevskyi, O.M. Bondarevska, S.T. Tolmachev, The use of mobile Internet devices in the formation of ICT component of bachelors in electromechanics competency in modeling of technical objects. CEUR Workshop Proceedings 2433, 413-428 (2019), http://ceur-ws.org/Vol2433/paper28.pdf. Accessed 10 Nov 2019

11. V.V. Tkachuk, V.P. Shchokin, V.V. Tron, The Model of Use of Mobile Information and Communication Technologies in Learning
Computer Sciences to Future Professionals in Engineering Pedagogy. CEUR Workshop Proceedings 2257, 103-111 (2018), http://ceurws.org/Vol-2257/paper12.pdf. Accessed 30 Nov 2018

12. M. Hillier, Bridging the digital divide with off-line e-learning. Distance education 39(1), 110-121 (2018)

13. J.W. Fresen, Embracing distance education in a blended learning model: challenges and prospects. Distance education 39(2), 224-240 (2017)

14. Moodle Statistics (2019), https://moodle.net/stats. Accessed 15 May 2019

15. S.V. Petrenko, Optimization of the results of using LMS Moodle in the mixed learning system in university. Information Technologies and Learning Tools 61(5), 141-150 (2017)

16. Kursy kafedry inozemnykh mov Kryvorizkoho natsionalnoho universytetu (Courses of Foreign Languages Department of Kryvyi Rih National University) (2020), http://mlib.knu.edu.ua/course/index.php?categoryid =324. Accessed 21 Mar 2020 